\title{
Study on Channel Features and Mechanism of Clinoptilolite Modified by $\mathrm{LaCl}_{3}$
}

\author{
Hai Lin ${ }^{1}$, Quanli Liu ${ }^{1}$, Yingbo Dong ${ }^{1}$, Yuefang Chen ${ }^{1}$, Hanxin Huo ${ }^{1} \&$ Shuyue Liu ${ }^{1}$ \\ ${ }^{1}$ School of Civil and Environmental Engineering, University of Science and Technology Beijing, Beijing, China \\ Correspondence: Hai Lin, School of Civil and Environmental Engineering, University of Science and \\ Technology Beijing, Beijing 100083, China. Tel: 86-138-0128-3734. E-mail: linhai@ces.ustb.edu.cn
}

Received: July 4, 2013 Accepted: July 30, 2013 Online Published: August 21, 2013

doi:10.5539/jmsr.v2n4p37 URL: http://dx.doi.org/10.5539/jmsr.v2n4p37

\begin{abstract}
Natural clinoptilolite was modified by $\mathrm{LaCl}_{3}$ at different ion concentrations, particularly focusing on the effects of $\mathrm{LaCl}_{3}$ on surface area, average pore width and pore volume distribution. And the structure was characterized by analyzing the X-ray diffraction (XRD), Fourier transform infrared (FT-IR) spectroscopy, and Energy Dispersive Spectroscopy (EDS). The results showed that the surface area, total pore volume and micropore area decreased after modified by $\mathrm{LaCl}_{3}$, while the average pore width increased, among which the micropore area most significantly changed. The result of IR indicated that $\mathrm{LaCl}_{3}$ did not enter into silico-oxygen tetrahedron skeleton to participate in skeleton vibration. The result of XRD showed that the crystallinity of the modified clinoptilolite was slightly reduced, and the diffraction peak deviated to small angle, but the crystal structure kept invariant. The result of EDS, FT-IR and XRD demonstrated that $\mathrm{LaCl}_{3}$ can be loaded on the surface and channels of clinoptilolite, which led to degradation in absorption performance of clinoptilolite to ammonia nitrogen while for phosphorus increases.
\end{abstract}

Keywords: clinoptilolite, surface area, average pore width, pore volume distribution, infrared spectrum, X-ray diffraction

\section{Introduction}

Clinoptilolite is a porous material with a regular structure and aperture less than $10 \mathrm{~nm}$, composed of aluminosilicate framework, cavities, channels, cations, and water molecules (Krishnarao \& Subrahmanyam, 2003). The specific surface area increases ten million times when the cube with side length of $10^{-2} \mathrm{~m}$ is divided into small cubes with side length of $10^{-9} \mathrm{~m}$. Thus the nanometer-grade grain has an ultra-high specific surface area, with many unique surface effects (Dou et al., 2009). Pores in the framework and channels of the clinoptilolite have a large internal surface area, and thus leads to the potential of adsorption (Zhang \& Shi, 2012; Chen, 2012). However, clinoptilolite has a poor adsorption performance to phosphate because its structure is negatively charged (Sun et al., 2010). Since rare earth metals have good affinity with phosphate ions, the application of rare earth metals in sewage treatment has become a new technical focusing point (Wu \& $\mathrm{Hu}$, 2011). Lanthanum is cheaper when compared with other rare earth elements and the effect of trace lanthanum on human health is not yet conclusive (Chen et al., 2010). Therefore lanthanum has been widely used to improve the performance of existing adsorbents and the phosphorus removal rate.

Currently, researchers often use lanthanum chloride and lanthanum nitrate for clinoptilolite modification, adjusting the $\mathrm{pH}$ by adding $\mathrm{NaOH}$ to make lanthanum hydroxide precipitate to the surface of clinoptilolite. Or roasting the clinoptilolite modified by lanthanum hydroxide in order to render lanthanum hydroxide decompose to lanthanum oxide (Zhang, Wan, \& Chang, 2011; Zhang, Zhou, \& Liu, 2012). Considering that the generation of lanthanum hydroxide needs to consume a lot of alkali, and if using lanthanum oxide to modify directly, the problems are that lanthanum oxide is insoluble in water and the pharmaceutical utilization is low. Furthermore, previous studies mostly concentrated on the performance of lanthanum-modified clinoptilolite to remove contaminants, but the pore characteristics of modified clinoptilolite particles and the action mechanism between lanthanum and clinoptilolite are little studied. Thus this article uses clinoptilolite as research subject, and uses $\mathrm{LaCl}_{3}$ to modify clinoptilolite. Then through analyzing the surface area, average pore width and pore volume distribution changes of modified and unmodified clinoptilolite, the influence law of clinoptilolite pore characteristics caused by modification can be found. Using EDS, IR, XRD, and etc. to characterize its structure, 
and analyze the action mechanism of $\mathrm{LaCl}_{3}$ and clinoptilolite particles.

\section{Materials and Methods}

\subsection{Materials and Equipments}

Sample materials: Natural clinoptilolite from Shenyang was chosen for sample materials. After grinding for a certain period of time and sieving, particle size of natural clinoptilolite between 0.12 to $0.16 \mathrm{~mm}$ was selected to be cleaned its surface impurities with deionized water, then it was oven-dried for preparation (Sun et al., 2012 ). The chemical concentrations of the sample were: $\mathrm{SiO}_{2}(68.75 \%), \mathrm{Al}_{2} \mathrm{O}_{3}(12.26 \%), \mathrm{Fe}_{2} \mathrm{O}_{3}(1.21 \%), \mathrm{CaO}(2.57 \%)$, $\mathrm{K}_{2} \mathrm{O}(2.83 \%), \mathrm{Na}_{2} \mathrm{O}(1.08 \%), \mathrm{MgO}(0.81 \%)$. XRD diffraction analysis showed that the clinoptilolite is calcium type clinoptilolite. During the test, the pharmacy used were of analytical pure, the water used was deionized water.

Test and analysis equipment: Rigaku DMAX-RB 12KW X-ray diffractometer, Nicolet 5MX Fourier Transform Infrared Spectrometer, V-Sorb 4800 Specific surface area and pore size analyzer, S250MK3 Scanning electron microscopy.

\subsection{The Preparation of Modified Clinoptilolite}

4 grams of natural clinoptilolite were dissolved in a series of solution with different concentration of lanthanum chloride, add deionized water to $200 \mathrm{ml}$. Natural clinoptilolite was dispersed in solution by prolonged stirring (2 $\mathrm{h}, 300 \mathrm{r} \cdot \mathrm{min}^{-1}$ ) with a magnetic stirrer. After filtering, the sample was oven-dried at $60{ }^{\circ} \mathrm{C}$ for $3 \mathrm{~h}$, place the samples in the dryer for preparation.

\subsection{Characterization of Modified Clinoptilolite}

\subsubsection{Characterization of Channel Characteristics Change}

Using V-Sorb 4800 specific surface area analyzer and pore size distribution, with static volumetric method for measuring principle, according to the nitrogen adsorption isotherm, using the BET method to calculate the specific surface area of the natural clinoptilolite and the modified, using BJH method to calculate the pore width distribution of mesoporesand macropores, HK method for micropore, micropore volume is calculated using t-plot method.

\subsubsection{Structural Characterization}

EDS was used for testing the composition difference between natural and modified clinoptilolite, XRD was used for testing their crystal structure change, and IR spectroscopy was for testing their group change.

\section{Results and Discussion}

\subsection{Pore Characteristics of $\mathrm{LaCl}_{3}$-Modified Clinoptilolite before and after the Modification}

Physical adsorption method-BET is now recognized as one of the best ways to determine specific surface area of solid. Pore size distribution is a characterization of the relationship between pore radius and pore volume of porous materials, and the $\mathrm{BJH}$ method is one of the most widely used methods to determine pore size distribution. But BJH ignores the enhancement of adsorption potential in micropores, only suitable for describing pore size distribution of mesopores. HK model considers the enhancement of microscopic potential, resulting in a good description of pore size distribution to some certain extent (Zhang et al., 2006).

Table 1 shows the data of surface area and pore size distribution of unmodified and modified clinoptilolite. The BET specific surface area of unmodified clinoptilolite is $38.54 \mathrm{~m}^{2} / \mathrm{g}$, and the total pore volume is $0.058 \mathrm{~cm}^{3} / \mathrm{g}$. T-plot method shows that micropore area is $6.49 \mathrm{~m}^{2} / \mathrm{g}$. After modification of $\mathrm{LaCl}_{3}$ with different concentrations, the surface area, total pore volume, micopore area decreased, but the average pore width increased. 
Table 1. Change of surface area and distribution of pore width about clinoptilolite modified by $\mathrm{LaCl}_{3}$

\begin{tabular}{ccccc}
\hline $\begin{array}{c}\text { Concentration of } \mathrm{LaCl}_{3} \\
(\%)\end{array}$ & $\begin{array}{c}\text { Surface area } \\
\left(\mathrm{m}^{2} / \mathrm{g}\right)\end{array}$ & $\begin{array}{c}\text { Average pore width } \\
(\mathrm{nm})\end{array}$ & $\begin{array}{c}\text { Total pore volume } \\
\left(\mathrm{cm}^{3} / \mathrm{g}\right)\end{array}$ & $\begin{array}{c}\text { T-plot micropore } \\
\text { area }\left(\mathrm{m}^{2} / \mathrm{g}\right)\end{array}$ \\
\hline 0 & 38.54 & 6.27 & 0.058 & 6.49 \\
0.1 & 30.41 & 6.70 & 0.050 & 5.14 \\
0.2 & 32.10 & 6.68 & 0.052 & 4.62 \\
0.3 & 31.92 & 6.88 & 0.045 & 5.67 \\
0.4 & 32.70 & 6.51 & 0.051 & 5.79 \\
0.5 & 30.86 & 7.01 & 0.052 & 4.91 \\
0.6 & 31.71 & 6.65 & 0.051 & 4.88 \\
\hline
\end{tabular}

Table 2. Change of surface area and distribution of pore width about clinoptilolite modified by $\mathrm{HCl}$

\begin{tabular}{|c|c|c|c|c|}
\hline Sample & $\begin{array}{l}\text { Surface area } \\
\qquad\left(\mathrm{m}^{2} / \mathrm{g}\right)\end{array}$ & $\begin{array}{l}\text { Average pore width } \\
(\mathrm{nm})\end{array}$ & $\begin{array}{c}\text { Total pore volume } \\
\left(\mathrm{cm}^{3} / \mathrm{g}\right)\end{array}$ & $\begin{array}{l}\text { T-Plot micropore } \\
\text { area }\left(\mathrm{m}^{2} / \mathrm{g}\right)\end{array}$ \\
\hline Natural Clinoptilolite & 38.54 & 6.27 & 0.058 & 6.49 \\
\hline $5 \% \mathrm{HCl}$ & 52.15 & 5.78 & 0.075 & 19.27 \\
\hline $5 \% \mathrm{HCl}+0.4 \% \mathrm{LaCl}_{3}$ & 41.54 & 6.16 & 0.064 & 15.29 \\
\hline
\end{tabular}

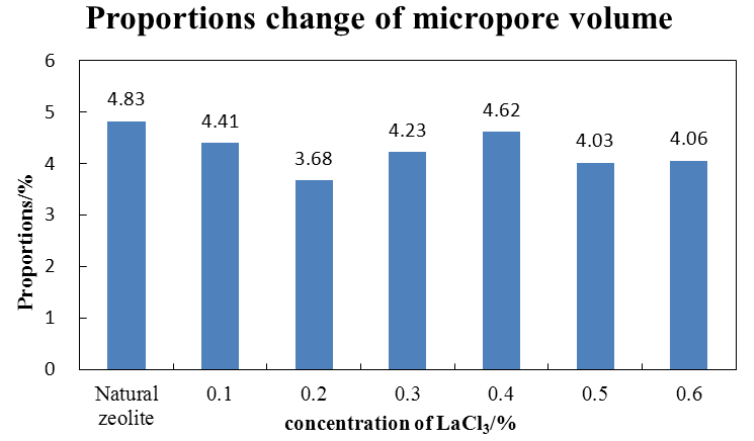

(a)

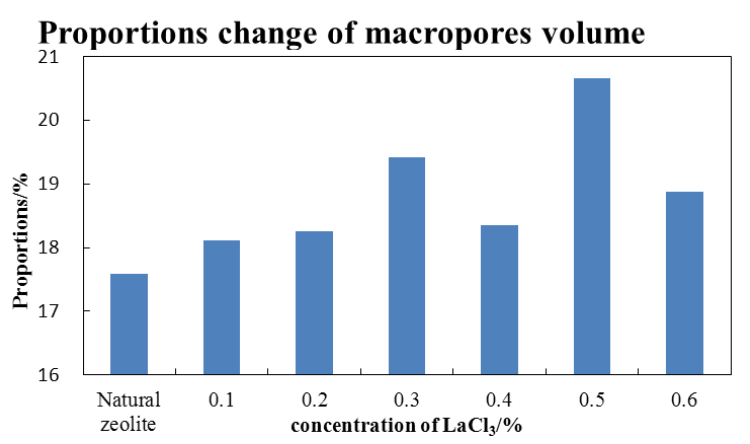

(c)

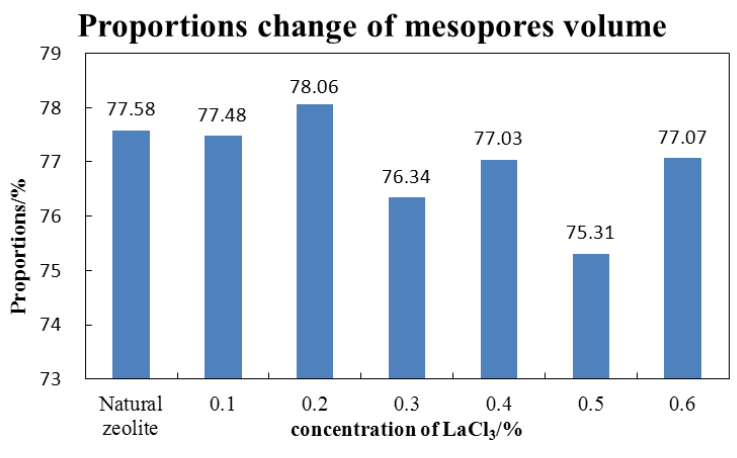

(b)

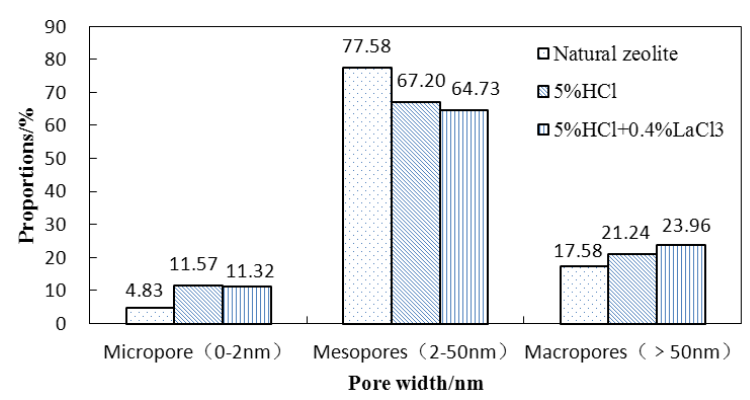

(d)

Figure 1. (a) Micropore volume proportions of clinoptilolite modified by $\mathrm{LaCl}_{3}$ at different ion concentrations; (b) Proportions change of mesopores volume; (c) Proportions change of macropores volume; (d) Pore volume distribution change of clinoptilolite modified by $5 \% \mathrm{HCl}, 5 \% \mathrm{HCl}$ with $0.4 \% \mathrm{LaCl}_{3}$

Figures 1(a-c) showed pore volume distributions of micropore, mesopore and macropore of clinptilolite modificated by $\mathrm{LaCl}_{3}$ with different concentrations, respectively. The results showed that different concentrations 
of $\mathrm{LaCl}_{3}$ had different effects on clinoptilolite modification, and pore volume distributions of micropore, mesopore and macropore were also different. This data of pore volume distribution was obtained by combining $\mathrm{BJH}$ adsorption method and $\mathrm{HK}$ model. The overall tests showed that $\mathrm{LaCl}_{3}$-modification caused decrease in pore volume ratio of micropore and mesopore, but increase in pore volume ratio of macropore, compared with the unmodified clinoptilolite. This is mainly due to that the adsorption sites of La presented in the surface and pores of clinoptilolite, thus a proportion of $\mathrm{LaCl}_{3}$ was loaded within channels in the clinoptilolite, and this part of La mainly existed in micropores and mesopores.

Through variations of specific surface area, average pore width, total pore volume, micropore surface area and pore volume distribution after modification by $\mathrm{LaCl}_{3}$ with different concentrations, it can be inferred that the decrease in pore volume ratio of micropore and mesopore will inevitably result in a large increase in the pore volume ratio of macropore, which was not enough to prove that modification can widen the channels, but it can prove that $\mathrm{LaCl}_{3}$ existed in the micropores and surface of the clinoptilolite, thereby causing reduction in the specific surface area and micropore area of modified clinoptilolite. As an adsorbent material, its structure feature has a great impact on its adsorption performance; so materials with large surface area and total pore volume have good adsorption performance. But the study found that phosphorus removal performance of the clinoptilolite is greatly improved after $\mathrm{LaCl}_{3}$ modification ( $\mathrm{Lin}$ et al., 2009), therefore the adsorption performance of clinoptilolite itself has not been improved after modification, while the phosphorus removal performance improvement is due to load of $\mathrm{LaCl}_{3}$, but the rich pores and large specific surface area of the clinoptilolite itself played a catalytic role in $\mathrm{LaCl}_{3}$ modification. It also can be found that the ammonia nitrogen adsorption performance of the clinoptilolite decreased after $\mathrm{LaCl}_{3}$ modification, it is due to ammonia adsorption effect are mainly ion exchange and physical adsorption (Hrenovic et al., 2008; Zhang et al., 2010; Widiastuti et al., 2011). Thus, $\mathrm{LaCl}_{3}$ does exist in the surface and pores of the clinoptilolite, plugging channels of the clinoptilolite, and resulting in degradation in ammonia adsorption performance (Li et al., 2012).

Since inorganic acid can dissolve some impurities plugging in the channels of the clinoptilolite, so that dredging the cavities and channels, and increasing pore volume and surface area of the clinoptilolite (Wender et al., 2011). To further prove that $\mathrm{LaCl}_{3}$ has been loaded to the surface and channels of the clinoptilolite after $\mathrm{LaCl}_{3}$ modification, the article first modified clinoptilolite with $\mathrm{HCl}(5 \%)$, and then further modified the clinoptilolite with $\mathrm{LaCl}_{3}$. Results are shown in Table 2 and Figure 1 (d), it can be found that the specific surface area of the clinoptilolite greatly increased after modified by $\mathrm{HCl}$, from $38.54 \mathrm{~m}^{2} / \mathrm{g}$ to $52.15 \mathrm{~m}^{2} / \mathrm{g}$. Total pore volume also increased from $0.058 \mathrm{~m}^{2} / \mathrm{g}$ to $0.075 \mathrm{~m}^{2} / \mathrm{g}$. Average pore width reduced to $5.78 \mathrm{~nm}$ after acid modification, which is due to a large number of micropores appeared after modification and micropore area increased from $6.49 \mathrm{~m}^{2} / \mathrm{g}$ to $19.27 \mathrm{~m}^{2} / \mathrm{g}$. Pore volume ratio of micropore increased dramatically, pore volume ratio of mesopore decreased, and pore volume ratio of macropore slightly increased, thereby resulting in an decrease in average pore width.

After treated by $\mathrm{LaCl}_{3}$, the pore characteristics of HCl-modified clinoptilolite also varied intensively. The specific surface area decreased from $52.15 \mathrm{~m}^{2} / \mathrm{g}$ to $41.54 \mathrm{~m}^{2} / \mathrm{g}$, the total pore volume decreased from $0.075 \mathrm{~m}^{2} / \mathrm{g}$ to $0.064 \mathrm{~m}^{2} / \mathrm{g}$, the micropore area decreased from $19.27 \mathrm{~m}^{2} / \mathrm{g}$ to $15.29 \mathrm{~m}^{2} / \mathrm{g}$, and the average pore width increased to $6.16 \mathrm{~nm}$. Pore volume ratio of micropore changed little, pore volume ratio of mesopore decreased from $67.20 \%$ to $64.73 \%$. Thus proved the modification effect of $\mathrm{LaCl}_{3}$ on clinoptilolite, and $\mathrm{LaCl}_{3}$ could load to the surface and pores of the clinoptilolite.

\subsection{Energy Dispersive Spectroscopy Analysis}

According to different X-ray photon characteristic energy of different elements, energy spectrometer was used to analyze the composition of the material. Element distribution of substances can be characterized by EDS analysis. Although the contents and distributions of the elements or oxides within the whole sample can't be quantitatively analyzed by EDS, the type of the each element contained in the sample and the trend of variation of the element content can be qualitatively analyzed. Table 3 showed the energy spectrum of the natural and modified clinoptilolite. The results showed that La did not exist in the natural clinoptilolite, and the composition of the clinoptilolite changed after $\mathrm{LaCl}_{3}$-modification, $\mathrm{La}$ accounted for $0.26 \%$ in the atomic ratio, the atomic ratios of other elements except $\mathrm{Si}$ all decreased. Proved that $\mathrm{LaCl}_{3}$ had loaded to the clinoptilolite, thereby improved phosphorus removal performance of the clinoptilolite. 
Table 3. EDS patterns of natural clinoptilolite and modified clinoptilolite (Atomic\%)

\begin{tabular}{cccccccccc}
\hline Element & $\mathrm{O}$ & $\mathrm{Si}$ & $\mathrm{Al}$ & $\mathrm{Ca}$ & $\mathrm{K}$ & $\mathrm{Na}$ & $\mathrm{Mg}$ & $\mathrm{La}$ & $\mathrm{Cl}$ \\
\hline $\begin{array}{c}\text { Natural } \\
\text { clinoptilolite }\end{array}$ & 67.12 & 23.5 & 5.78 & 0.83 & 1.39 & 0.86 & 0.52 & 0 & 0 \\
$\begin{array}{c}\text { Modified } \\
\text { clinoptilolite }\end{array}$ & 66.88 & 25.27 & 4.64 & 0.73 & 1.36 & 0.52 & 0.27 & 0.26 & 0.07 \\
\hline
\end{tabular}

\subsection{Infrared Spectrum Analysis}

Infrared spectrum is a useful method in the study of the structure of clinoptilolite ( $\mathrm{Li}$ et al., 2009). Infrared spectrum is based on the measurement of bond vibration or rotational frequency of the molecules, including stretching vibration of the bond and flexural vibration of the bond. Therefore, it has already been applied to determine the overall skeleton structure of clinoptilolite. Generally, the wave-number of absorption spectrum of clay minerals ranges from 400 to $4000 \mathrm{~cm}^{-1}$ and belongs to the middle infrared region (Shi et al., 2013).

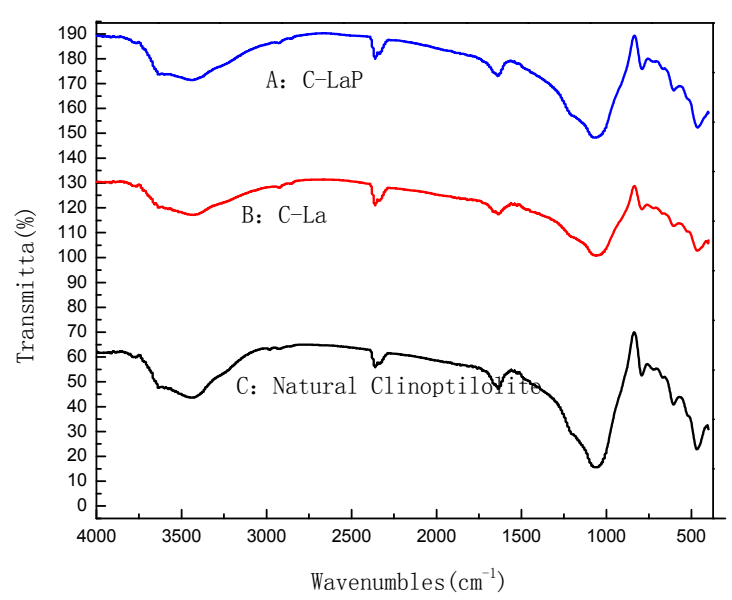

Figure 2. The FT-IR spectra of natural clinoptilolite, clinoptilolite modified by $\mathrm{LaCl}_{3}(\mathrm{C}-\mathrm{La})$, modified clinoptilolite after phosphate adsorption(C-LaP)

Clinoptilolite belongs to the typical tectosilicate and the strongest adsorption band lies between 950 and 1200 $\mathrm{cm}^{-1}$ and the main bond vibrations include $\mathrm{Si}(\mathrm{Ai})-\mathrm{O}$, which includes the stretching vibration of $\mathrm{Si}(\mathrm{Ai})-\mathrm{O}$ and flexural vibration of O-Si (Ai)-O and Si-O-Si (Ai), and the tetrahedron skeleton vibration of $\mathrm{Si}$ (Ai)-O (Yang et al., 2006). The asymmetric stretching vibration of $\mathrm{Si}(\mathrm{Ai})-\mathrm{O}$ is $1150 \sim 930 \mathrm{~cm}^{-1}$, the symmetric stretching vibration of $\mathrm{Si}-\mathrm{O}-\mathrm{Si}$ (Ai) is $800 \sim 760 \mathrm{~cm}^{-1}$, the bicyclo-vibration of O-Si (Ai)-O and flexural vibration of Si-O are near $600 \sim 440 \mathrm{~cm}^{-1}$, the flexural vibration of $\mathrm{O}-\mathrm{H}$ is $1640 \sim 1620 \mathrm{~cm}^{-1}$ and stretching vibration of $\mathrm{O}-\mathrm{H}$ is $3700 \sim 3200 \mathrm{~cm}^{-1}$ (Kawashita et al., 2010).

From Figure 2, it is revealed that there is no change in the FT-IR between the modified and natural clinoptilolite. The bond peak and strength of Si-O, Si-O-Si (Ai) and Si-O-Si (Ai) are within the allowed error range. No new key band is observed in the clinoptilolites modified by $\mathrm{LaCl}_{3}$. If $\mathrm{La}$ enters the tetrahedron skeleton and joins the skeleton vibration, the flexural vibration of Si-O loaded with $\mathrm{La}$ will be stronger because the covalent radius of $\mathrm{La}$ is larger. Meanwhile, the flexural vibration of $\mathrm{Si}-\mathrm{O}-\mathrm{Si}$ (Ai) becomes more difficult after the modification and wave number decreases. Therefore, $\mathrm{La}$ is loaded only to the surface of clinoptilolites and does not enter its tetrahedron skeleton structure and joins the skeleton vibration. Figure 2 also shows that FT-IR of the modified clinoptilolites after phosphorus adsorption corresponds with that before phosphorus adsorption and no new key band is observed, which indicates that during the phosphorus adsorption process, phosphorus only reacts with $\mathrm{La}$ loaded on the surface and pore canal of clinoptilolites and does not enter its tetrahedron skeleton structure, neither react chemically with clinoptilolites, which may arise the new key band of P-O.

In conclusion, $\mathrm{La}$ is only loaded to the surface and pore canal of clinoptilolites and does not enter its tetrahedron 
skeleton structure and joins the skeleton vibration. Besides, the La loaded to the surface and pore canal of clinoptilolites constitutes the adsorption site for phosphorus, which enhances the adsorption ability of clinoptilolite for phosphorus.

\subsection{XRD Analysis}

XRD, which makes use of the diffraction phenomena of X-ray in the crystal, is used to analyze the crystal structure, parameters and defect of the materials. It is the most effective way to analyze the space structure of clinoptilolite (Castaldia et al., 2008).

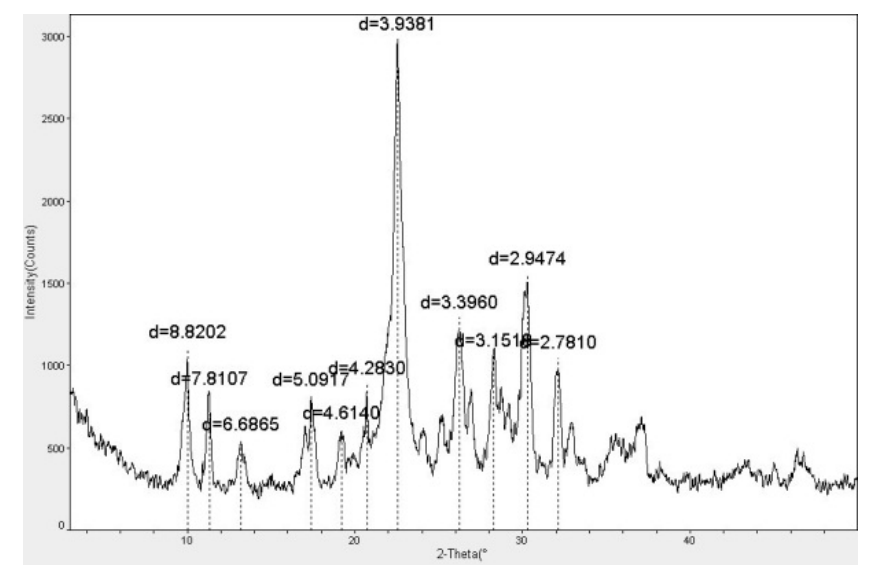

Figure 3. XRD of the natural clinoptilolite

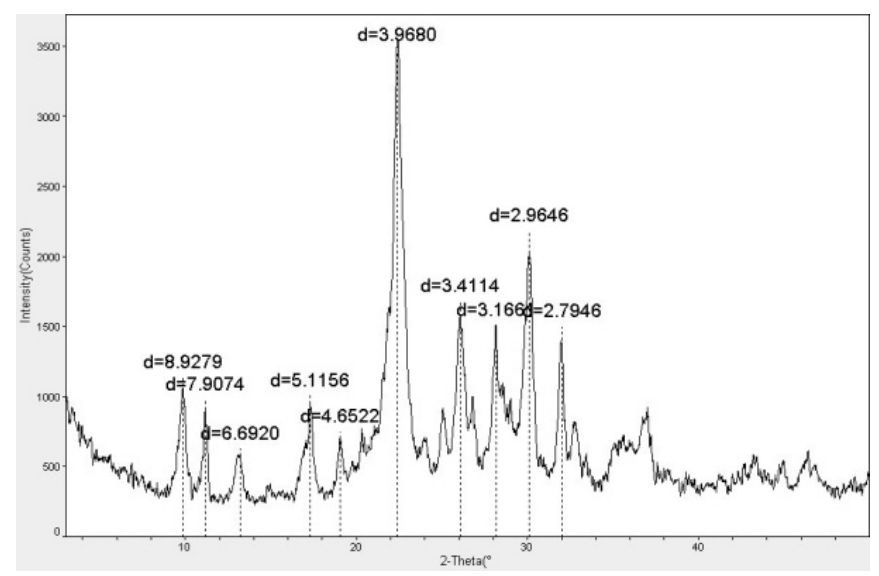

Figure 4. XRD of clinoptilolite modified by $\mathrm{LaCl}_{3}$

Comparing Figure 3 and Figure 4 with the standard maps, the diffraction peaks of this natural clinoptilolite are mainly composed of clinoptilolite (about $22.5^{\circ}, 25^{\circ}$ and $30^{\circ}$ ), $\mathrm{SiO}_{2}$ (about $22^{\circ}$ and $44.5^{\circ}$ ) and other silicon and aluminium oxides (about $39^{\circ}, 58^{\circ}$ and $68^{\circ}$ ) (Karapınar, 2009). Clinoptilolites before and after modification both show obvious crystal structure, with nearly same spectral lines and few changes in the number of diffraction peaks. This indicates that the overall skeleton structure and structural holes are not changed by the modification process. Comparing Figure 3 with Figure 4, there is a slight decrease in the intensity of the main diffraction peak, which means that the degree of crystallinity of the clinoptilolites modified by $\mathrm{LaCl}_{3} \mathrm{decease}$ slightly. There is not obvious change in the interplanar spacing between the main diffraction peaks. However, there is a trend that the diffraction peaks of modified clinoptilolite shift to small angles, which indicates that the aperture of modified clinoptilolite has the trend to increase. This is corresponded with the specific surface area and pore size analysis. The diffraction peak of $\mathrm{La}$ is not observed from the modified clinoptilolite, which indicates that La is only loaded to the surface of clinoptilolite and does not change its structure. 


\section{Conclusions}

(1) After modified by $\mathrm{LaCl}_{3}$ of different concentrations, the surface area, total pore volume and micropore area of clinoptilolites decreased equally and the average pore width increases. The pore distribution test shows that the volume proportion of micropore and mesopore decreases while the volume proportion of macropore increases. Combined with the EDS test, it showed that $\mathrm{LaCl}_{3}$ is loaded on the surface and pore canal of clinoptilolites, so its adsorption for ammonia nitrogen decreases while for phosphorus increases as a result of the presence of La.

(2) After modified by hydrochloric acid, the surface area, total pore volume of clinoptilolites increase greatly, and the volume proportion of micropore increases greatly while the volume proportion of mesopore decreases and the volume proportion of macropore increases slightly. After modified by $\mathrm{LaCl}_{3}$, the surface area, total pore volume and micropore area of the hydrochloric acid-modified clinoptilolites change greatly. This verifies that $\mathrm{LaCl}_{3}$ can be loaded on the surface and pore canal of clinoptilolites.

(3) The infrared spectrum shows that La is only loaded to the surface and pore canal of clinoptilolites and does not enter its tetrahedron skeleton structure and the skeleton shake. From another aspect, the loaded La forms the adsorption site for phosphorus which enhances the adsorption ability of clinoptilolite for phosphorus.

(4) XRD spectrums of modified and unmodified clinoptilolites show that the crystallinity of the clinoptilolites modified by $\mathrm{LaCl}_{3}$ decease slightly, there is not obvious change in the interplanar spacing, and there is a trend that the diffraction peaks of modified clinoptilolite shift to small angles. However, the crystal structure is not changed. La is only loaded to the surface of clinoptilolite and does not change its overall skeleton structure and structural holes.

\section{Acknowledgements}

This work was supported by the National Natural Science Foundation of China (51174017).

\section{References}

Castaldia, P., Santonaa, L., Enzob, S., \& Melisa, P. (2008). Sorption processes and XRD analysis of a natural zeolite exchanged with $\mathrm{Pb}^{2+}, \mathrm{Cd}^{2+}$ and $\mathrm{Zn}^{2+}$ cations. Journal of Hazardous Materials, 156(1/3), 428-434. http://dx.doi.org/10.1016/j.jhazmat.2007.12.040

Chen, C. G., Ying, H. M., \& Du, Y. J. (2012). Study on Removing Phosphorus from Wastewater by Zeolite. Guangdong Chemical Industry, 39(3), 132-133. Retrieved from http://www.cnki.com.cn/Article/CJFDTotal-GDHG201003017.htm

Chen, H. H., Huang, L. M., \& Wu, F. H. (2010). Study on defluoridation of water using lanthanum-modified permutite. Journal of Environment and Healthy, 27(10), 868-871. Retrieved from http://www.cnki.com.cn/Article/CJFDTotal-HJYJ201010009.htm

Dou, Z. F., Yu, W. H., \& Feng, Y. H. (2009). Uncertianty Evaluation of Measurement of Specific Surface Area and Pore Size Distribution of Porous Material. Natural Science Journal of Hainan University, 27(4), 353-357. http://dx.doi.org/10.3969/j.issn.1004-1729.2009.04.010

Fan, C. H., \& Zhang, Y. C. (2012). The Characteristics of Crystallization Kinetics on zeolite by Scanning Electron Microscope (SEM) and X-ray Diffraction (XRD). Non-Metallic Mines., 35(5). http://dx.doi.org/10.3969/j.issn.1000-8098.2012.05.002

Hrenovic, J., Rozic, M., \& Sekovanic, L. (2008). Interaction of surfactant-modified zeolites and phosphate accumulating bacteria. Journal of Hazardous Materials, 156(1/3), 576-582. http://dx.doi.org/10.1016/j.jhazmat.2007.12.060

Karapınar, N. (2009). Application of natural zeolite for phosphorus and ammonium removal from aqueous $\begin{array}{lllll}\text { solutions. Journal of Hazardous } & \text { Materials, } & \text { 170(2/3), } & \text { 1186-1191. }\end{array}$ http://dx.doi.org/10.1016/j.jhazmat.2009.05.094.

Kawashita, M., Tsuneyama, S., \& Miyaji, F. (2000). Antibacterial silver-containing silica glass prepared by sol-gel method. Biomaterials, 21(4), 393-398. http://dx.doi.org/10.1016/S0142-9612(99)00201-X

Krishnarao, R. V., \& Subrahmanyam, J. (2003). Studies on the formation of TiB2 through carbothermal and $\mathrm{B}_{2} \mathrm{O}_{3}$ reduction of $\mathrm{TiO}_{2}$. Materials Science and Engineering, 362, 145-151. http://dx.doi.org/10.1016/S0921-5093(03)00523-9

Li, J., Lin, J. W., \& Zhan, Y. H. (2012). Removal of phosphate and ammonium from aqueous solution by lanthanum-modified zeolite. Journal of Shanghai Ocean University, 21(5), 800-808. Retrieved from 
http://www.cnki.com.cn/Article/CJFDTotal-SSDB201205023.htm

Li, T. X., Yang, W. W., \& Zhu, W. Y. (2009). Component transformation mechanism of mesoporous composite materials studied by FTIR spectroscopy and X- ray diffraction. Journal of University of Science and Technology Beijing, 31(6), 739-743. http://dx.doi.org/10.3321/j.issn:1001-053X.2009.06.013

Lin, H., Jiang, L. Y., \& Zhao, Z. Y. (2009). Adsorption materials of nitrate and phosphate removal in secondary effluent advanced treatment. Journal of University of Science and Technology Beijing, 31(5), 551-556. http://dx.doi.org/10.3321/j.issn:1001-053X.2009.05.005

Shi, Y. C., Zhang, W., \& Zhang, H. X. (2013). Effect of cyclohexene on thiophene adsorption over NaY and $\begin{array}{lllll}\text { LaNaY zeolites. Fuel Processing } & \text { 24-32. }\end{array}$ http://dx.doi.org/10.1016/j.fuproc.2013.01.008

Sun, X. B., Han, J. Z., \& Pan, H. Y. (2010). Study on modification and phosphate-adsorption capacity of zeolite. Journal of Harbin University of Commerce (Natural Sciences Edition), 26(2), 161-164. Retrieved from http://www.cnki.com.cn/Article/CJFDTotal-HLJS201002008.htm

Sun, Y. L., Ling, J. W., \& Huang, H. (2012). Simultaneous removal of ammonium and phosphate from aqueous solution by natural zeolite. Chinese Journal of Environmental Engineering, 6(8), 2470-2476. Retrieved from http://www.cnki.com.cn/Article/CJFDTotal-HJJZ201208003.htm

Wender, S. C., Douglas, F. M., \& Fernando, R. G. (2011). Phosphate adsorption on chemically modified

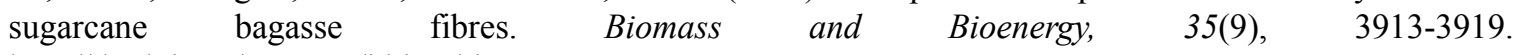
http://dx.doi.org/10.1016/j.biombioe.2011.06.014

Widiastuti, N., Wu, H. W., \& Ang, H. M. (2011). Removal of ammonium from greywater using natural zeolite. Desalination, 277(1/3), 15-23. http://dx.doi.org/10.1016/j.desal.2011.03.030

Wu, C. H., \& Hu, Y. X. (2011). Synthesis and characterization of citric acid rare earth complexes. Journal of $\begin{array}{lllll}\text { Beijing Institute of Petro-chemical } & \text { Technology, } & \text { 19(4), } & \text { 7-10. }\end{array}$ http://dx.doi.org/10.3969/j.issn.1008-2565.2011.04.002

Zhang, C., Gao, C., \& Lu, X. S. (2006). Characterization of pore size distribution of porous activated carbons. Ion Exchange and Adsorption, 22(1), 187-192. Retrieved from http://www.cnki.com.cn/Article/CJFDTotal-LJYX200602013.htm.

Zhang, L., Wan, L. H., \& Chang, N. (2011). Removal of phosphate from water by activated carbon fiber loaded with lanthanum oxide. Journal of Hazardous Materials, 190(1-3), 848-855. http://dx.doi.org/10.1016/j.jhazmat. 2011.04.021

Zhang, L., Zhou, Q., \& Liu, J. Y. (2012). Phosphate adsorption on lanthanum hydroxide-doped activated carbon fiber. Chemical Engineering Journal, 185-186, 160-167. http://dx.doi.org/10.1016/j.cej.2012.01.066

Zhang, M., \& Shi, P. J. (2012). Sutdy on the structure character of zeolite and its application in water treatment. Southwest Water \& Wastewater, 34(1), 31-36. Retrieved from http://www.cnki.com.cn/Article/CJFDTotal-XNGP201201011.htm

Zhang, X. Y., Wu, Z. C., \& Wang, Z. W. (2010). Adsorption characteristics of ammonium ions by natural zeolite powder. China Environmental Science, 30(5), 609-614. Retrieved from http://www.cnki.com.cn/Article/CJFDTotal-ZGHJ201005008.htm

\section{Copyrights}

Copyright for this article is retained by the author(s), with first publication rights granted to the journal.

This is an open-access article distributed under the terms and conditions of the Creative Commons Attribution license (http://creativecommons.org/licenses/by/3.0/). 